\title{
Impact of Watercourse Lining on Water Conservation in the Gadeji Minor Command, Sindh, Pakistan
}

\author{
GHULAM SHABIR SOLANGI*, NEK MUHAMMAD KATBAR**, JAVED IQBAL KHOKHAR***, \\ SALLAHUDDIN PANHAWAR*, AND NABI BUX BHATTI* \\ RECEIVED 04.10.2016 ON ACCEPTED ON 22.11.2016 \\ ABSTRACT
}

\begin{abstract}
Looming water scarcity could be curtailed with intelligent water losses control. Present study was designed to assess the relative effect of watercourse lining in prospect of seepage minimization. Qualitative as well as quantitative analysis was undertaken using water conveyance efficiency, annual water saving, increase in cropping intensities, time and land saving along with labor saving indictors over Gadeji minor in Sindh, Pakistan. Primary data was collected from field measurements while secondary data was gathered from NPIW (National Program for Improvement of Watercourses), Irrigation Department, personal interviews and site survey. The analysis revealed that lining of $30 \%$ initial portion of watercourses resulted average annual water saving of $\mathbf{1 0 . 3 2}$ hectare-m. Similarly, the cropping intensity increased $15 \%$ in Rabi and $14 \%$ in Kharif seasons. Crop yield increased by $17 \%$ for wheat crop, $14 \%$ for cottoncrop, $12 \%$ for sugarcane, $17 \%$ for chilies, $11 \%$ for onion crop and $20 \%$ for rice crop after lining the selected watercourses. Thus, it is concluded that watercourse lining has noticeable effect for seepage control which yielded a significant water saving. In future, economic viability of watercourse lining may be assessed for obtaining optimum benefits.
\end{abstract}

Key Words: Watercourse lining, Conveyance Efficiency, Water Saving, Cropping Intensity.

\section{INTRODUCTION}

$\mathrm{P}$ akistan is blessed with various natural resources including land and water. Water is a scarce source which is the life blood of agriculture. Irrigated agriculture plays a vital role in the economy of many developing countries. With the increase of population, the water demand among agricultural, urban, industrial and environmental sectors is also increasing [1-5]. A huge amount of seepage losses deteriorates irrigation system, causes water-logging and soil salinity problems in agricultural lands. In Pakistan, per capita water availability which was $5260 \mathrm{~m}^{3}$ in 1951 is reduced to $1032 \mathrm{~m}^{3}$ [6].

Irrigation system of Pakistan consists of barrages, headworks, main canals, branch canals, distributaries, minors and watercourses only.

Corresponding Author: (Email: solangi_shabir@yahoo.com)

* US-Pakistan Centres for Advanced Studies in Water, Mehran University of Engineering \& Technology, Jamshoro.

** Department of Basic Sciences \& Related Studies, Mehran University of Engineering \& Technology,

Shaheed Zulfiqar Ali Bhutto Campus, Khairpur Mir's.

*** Water Management Officer, Sindh Irrigated Agriculture Productivity Enhancement Project, Govt. of Sindh, Karachi.

Mehran University Research Journal of Engineering \& Technology, Volume 37, No. 1, January, 2018 [p-ISSN: 0254-7821, e-ISSN: 2413-7219] 
Operation and maintenance of primary and secondary canals is the responsibility of provincial Irrigation Department; but farmers are responsible for operation and maintenance of tertiary canals (watercourses). Lack of technical skills and poor maintenance, these watercourses are often deteriorated, resulting in excessive conveyance losses. The conveyance efficiency of watercourses before improvement is less than 60\% [7]. The conveyance losses at field level may be reduced by lining of minor and its watercourses [8]. Lining of main watercourses attempts to save good quality canal water [9]. It is reported that farmers do not operate and maintain the watercourses appropriately; therefore, water never reaches the farmers fields properly [10]. In order to investigate the extent of conveyance losses in canal irrigation system, several studies have been conducted.

Keeping in view the huge water losses, the Government of Pakistan launched OFWM (On Farm Water Management) project in 1977. Later on various OFWM projects were implemented with the help of different donor agencies. Similarly, since 2005, NPIW has been launched in all the provinces of Pakistan with the objective to: improve watercourses, reduce seepage losses and save considerable quantum of water. Under this program, $30 \%$ length of watercourses is to be lined by the participation of WUAs (Water Users' Associations).
Also various studies were conducted for impact assessment of OFWM activities including watercource improvement. The monitoring and evaluation of this program reveals that after lining of watercourses, the conveyance efficiency as well as yields per acre has been increased [11]. The results of these studies were so encouraging that it paved the way for improvement of all watercourses throughout the country.

The present study was conducted to assess the effect of watercourses lining on water conservation in terms of conveyance efficiency, annual water saving, increase in cropping intensities, time saving, and labor, etc.

\section{MATERIALS AND METHOD}

\subsection{The Study Area}

Gadeji minor is an irrigation channel located in district Khairpur Mir's, Sindh, Pakistan between Longitudes 68²8’45.90"E, 68²6’22.50"E and Latitudes 27¹5’17.38"N, $27^{\circ} 14^{\prime} 4.48$ "N (Fig. 1).

Through consultation of NPIW, FT (Field Team) Sobhodero, six sample watercourses improved under NPIW program were selected in order to evaluate the effect of their lining on water conservation. The salient features of the selected sample watercourses are described in Table 1.

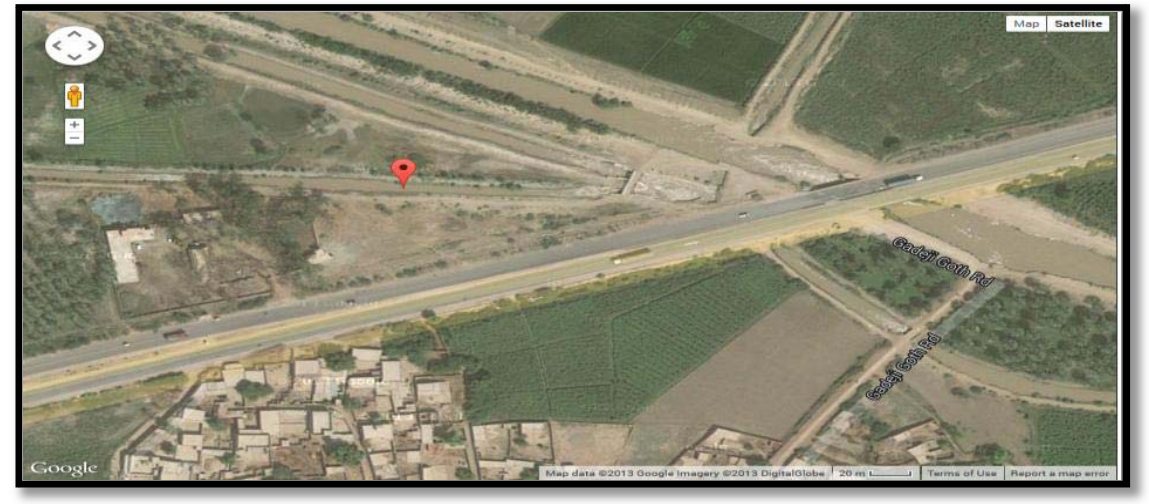

FIG. 1. LOCATION OF GADEJI MINOR IN GOOGLE MAP

Mehran University Research Journal of Engineering \& Technology, Volume 37, No. 1, January, 2018 [p-ISSN: 0254-7821, e-ISSN: 2413-7219] 
Data regarding this study was collected through different ways such as field measurement, NPIW, Irrigation Department, personal interviews and site survey.

\subsection{Data Collection}

\subsubsection{Discharge Measurement}

For rectangular brick lined section of the watercourses, steel tape was used: to measure area of segments and current meter with two point method (depth of water $>0.6$ $\mathrm{m}$ ) as well as one point method (depth of water $<0.6 \mathrm{~m}$ ) to determine velocity. The relation $\mathrm{V}=0.123 \mathrm{~N}$ (Revolution/ sec) +0.007 was used to observe velocity of flow and consequently the inlet and outlet discharges at the required sections of the selected watercourses were determined by multiplying the respective $\mathrm{x}$-sectional areas with respective velocities.

However, for unlined sections of the watercourses, cut throat flumes having size of throat width and length of flume as (8' 'x3') were used to determine discharges at the required points of the sample watercourses.

\subsubsection{Conveyance Losses and Conveyance Efficiency}

Inflow and outflow method was used to determine conveyance losses as well as conveyance efficiency in the lined and unlined sections of the selected watercourses. Following formulae was used to observe conveyance losses as well as conveyance efficiency in the selected sample watercourses.

Conveyance Loss $(\%)=\frac{\mathrm{Q}_{\mathrm{i}}-\mathrm{Q}_{\mathrm{o}}}{\mathrm{Q}_{\mathrm{i}}} * 100$

Conveyance Efficiency $(\%)=\frac{\mathrm{Q}_{0}}{\mathrm{Q}_{\mathrm{i}}} * 100$

Where, $\mathrm{Q}_{\mathrm{i}}$ and $\mathrm{Q}_{\mathrm{o}}$ are inflow and out flow rates observed in $\mathrm{m}^{3} / \mathrm{sec}$ respectively.

\subsubsection{Water Saving}

Water saving in the selected watercourses was estimated by subtracting \%age conveyance losses observed in unlined portions of sample watercourses from \%age conveyance losses observed in lined portions of the sample watercourses.

\subsection{Crop Data Collection}

\subsubsection{Selection of Respondent for Questionnaire Survey}

The data regarding preand post-improvement of selected watercourses was collected by interviewing the farmers (Total 48 sample farmers, 03 at head, 03 at middle and 02 at tail of each of the selected watercourses).

TABLE 1. SALIENT FEATURES OF SELECTED SAMPLE WATERCOURSES OF GADEJI MINOR

\begin{tabular}{|c|c|c|c|c|c|c|}
\hline No. & $\begin{array}{c}\text { Watercourses } \\
\text { No. }\end{array}$ & $\begin{array}{c}\text { CCA } \\
(\text { hectares })\end{array}$ & $\begin{array}{c}\text { Design Discharge } \\
(\text { cumecs })\end{array}$ & $\begin{array}{c}\text { Total Length } \\
(\mathrm{km})\end{array}$ & $\begin{array}{c}\text { Lined Length } \\
(\mathrm{km})\end{array}$ & $\begin{array}{c}\text { Unlined Length } \\
(\mathrm{km})\end{array}$ \\
\hline 1. & $8-\mathrm{R}$ & 63 & 0.015 & 1.00 & 0.30 & 0.70 \\
\hline 2. & $9-\mathrm{L}$ & 51 & 0.015 & 1.20 & 0.36 & 0.84 \\
\hline 3. & $11-\mathrm{R}$ & 156 & 0.0416 & 3.81 & 1.143 & 2.667 \\
\hline 4. & $15-\mathrm{R}$ & 142 & 0.0425 & 1.50 & 0.45 & 1.05 \\
\hline 5. & $16-\mathrm{L}$ & 107 & 0.0311 & 1.50 & 0.45 & 1.05 \\
\hline 6. & $18-\mathrm{L}$ & 94 & 0.0283 & 1.20 & 0.36 & 0.84 \\
\hline \multicolumn{7}{|c|}{ Source: Irrigation West Division Khairpur Mir's, NPIW FT Sobhodero (2016) } \\
\hline
\end{tabular}

Mehran University Research Journal of Engineering \& Technology, Volume 37, No. 1, January, 2018 [p-ISSN: 0254-7821, e-ISSN: 2413-7219] 


\subsubsection{Cropping Intensity, Pattern and Crop Yield}

To observe the cropping intensity, cropping pattern and crop yield, a field survey was carried out through questionnaire by interviewing the farmers in the command area of selected six watercourses for the crop season 20152016.

Collected field data was recorded and saved in Microsoft Excel sheets to make a comprehensive analysis of the collected data [12].

\section{RESULTS AND DISCUSSION}

\subsection{Conveyance Losses in Improved and Unimproved Sections of the Sample Watercourses}

The observed conveyance losses in lined and unlined sections of the sample watercourses are described in Tables 2-3 and shown in Fig. 2.
Comparing the average conveyance loss of about 13\% from unlined sections to the average conveyance loss of $01 \%$ from lined sections of the watercourses, it was estimated that the lining reduced water loss by $12 \%$.

However, the conveyance losses in the unimproved portions of the selected w/cs occurred mainly due to seepage through bed and banks of watercourse and evaporation losses [12].

\subsection{Conveyance Efficiency}

Table 4 and Fig. 3 shows that average conveyance efficiency in lined watercourses is $99 \%$, while that in unlined watercourses is $87 \%$. However, the overall change in conveyance efficiency was observed as12\% however, the significant change in conveyance efficiency (i.e. 24\%) observed in watercoursesNo. 11-R, this is because of its more unlined length i.e. $2.667 \mathrm{kms}$. The reason of less

TABLE 2. CONVEYANCE LOSSES IN LINED SECTIONS OF WATERCOURSES

\begin{tabular}{|c|c|c|c|c|c|c|}
\hline No. & $\begin{array}{c}\text { Watercourses } \\
\text { No. }\end{array}$ & $\begin{array}{c}\text { Lined Length } \\
(\mathrm{km})\end{array}$ & Inlet Q (cumecs) & Outlet Q (cumecs) & $\begin{array}{c}\text { Loss } \\
(\%)\end{array}$ & $\begin{array}{c}\text { Conveyance Loss/ } \\
\mathrm{km}(\%)\end{array}$ \\
\hline 1. & $8-\mathrm{R}$ & 0.30 & 0.0148 & 0.0147 & 0.68 & 2.3 \\
\hline 2. & $9-\mathrm{L}$ & 0.36 & 0.0150 & 0.0149 & 0.67 & 1.9 \\
\hline 3. & $11-\mathrm{R}$ & 1.143 & 0.0415 & 0.0407 & 1.93 & 1.7 \\
\hline 4. & $15-\mathrm{R}$ & 0.45 & 0.0423 & 0.0418 & 0.97 & 2.6 \\
\hline 5. & $16-\mathrm{L}$ & 0.45 & 0.0308 & 0.0305 & 0.67 & 1.9 \\
\hline 6. & $18-\mathrm{L}$ & 0.36 & 0.0297 & 0.0295 & & $1.01 \%$ \\
\hline
\end{tabular}

TABLE 3. CONVEYANCE LOSSES IN UNLINED SECTIONS OF WATERCOURSES

\begin{tabular}{|c|c|c|c|c|c|c|}
\hline No. & $\begin{array}{c}\text { Watercourses } \\
\text { No. }\end{array}$ & $\begin{array}{c}\text { Unlined Length } \\
(\mathrm{km})\end{array}$ & Inlet Q (cumecs) & Outlet Q (cumecs) & $\begin{array}{c}\text { Loss (\%) } \\
\mathrm{km}(\%)\end{array}$ \\
\hline 1. & $8-\mathrm{R}$ & 0.70 & 0.0147 & 0.0132 & 10.20 & 14.6 \\
\hline 2. & $9-\mathrm{L}$ & 0.84 & 0.0149 & 0.0134 & 10.07 & 12.0 \\
\hline 3. & $11-\mathrm{R}$ & 2.667 & 0.0407 & 0.0301 & 26.04 & 9.8 \\
\hline 4. & $15-\mathrm{R}$ & 1.05 & 0.0418 & 0.0377 & 10.82 & 10.3 \\
\hline 5. & $16-\mathrm{L}$ & 1.05 & 0.0305 & 0.0272 & 11.53 & 13.7 \\
\hline 6. & $18-\mathrm{L}$ & 0.84 & 0.0295 & 0.0261 & $13.13 \%$ & \\
\hline
\end{tabular}

Mehran University Research Journal of Engineering \& Technology, Volume 37, No. 1, January, 2018 [p-ISSN: 0254-7821, e-ISSN: 2413-7219] 
conveyance efficiency in unlined portion of watercourses is absolutely due to lack of proper maintenance of the watercourses, presence of vegetation, improper alignment of watercourses, etc [12]. Thus the conveyance efficiency was improved by $12 \%$ due to the lining of the watercourses. Similar results have been obtained by Mangrio et. al. [12] in their feasibility study at Mureed Distributary, Sindh, Pakistan.

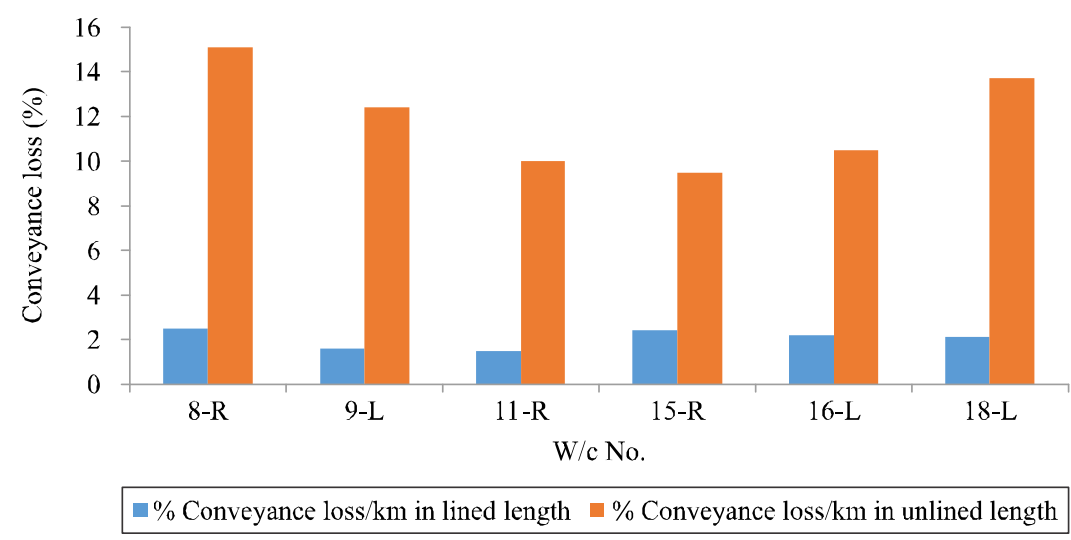

FIG. 2. PERCENTAGE CHANGE IN CONVEYANCE LOSSES OBSERVED IN IMPROVED AND UNIMPROVED REACHES OF THE SELECTED WATERCOURSES

TABLE 4. CONVEYANCE EFFICIENCY IN LINED AND UNLINED PORTIONS OF THE WATERCOURSES

\begin{tabular}{|c|c|c|c|c|}
\hline No. & $\begin{array}{c}\text { Watercourses } \\
\text { No. }\end{array}$ & $\begin{array}{c}\text { Conveyance Efficiency in Lined Portion } \\
(\%)\end{array}$ & $\begin{array}{c}\text { Conveyance Efficiency in Unlined Portion } \\
(\%)\end{array}$ & $\begin{array}{c}\text { Increase } \\
(\%)\end{array}$ \\
\hline 1. & $8-\mathrm{R}$ & 99 & 89 & 10 \\
\hline 2. & $9-\mathrm{L}$ & 99 & 90 & 9 \\
\hline 3. & $11-\mathrm{R}$ & 98 & 90 & 24 \\
\hline 4. & $15-\mathrm{R}$ & 99 & 89 & 10 \\
\hline 5. & $16-\mathrm{L}$ & 99 & 88 & 11 \\
\hline 6. & $18-\mathrm{L}$ & 99 & $87 \%$ & $12.16 \%$ \\
\hline \multicolumn{7}{r}{} \\
\hline
\end{tabular}

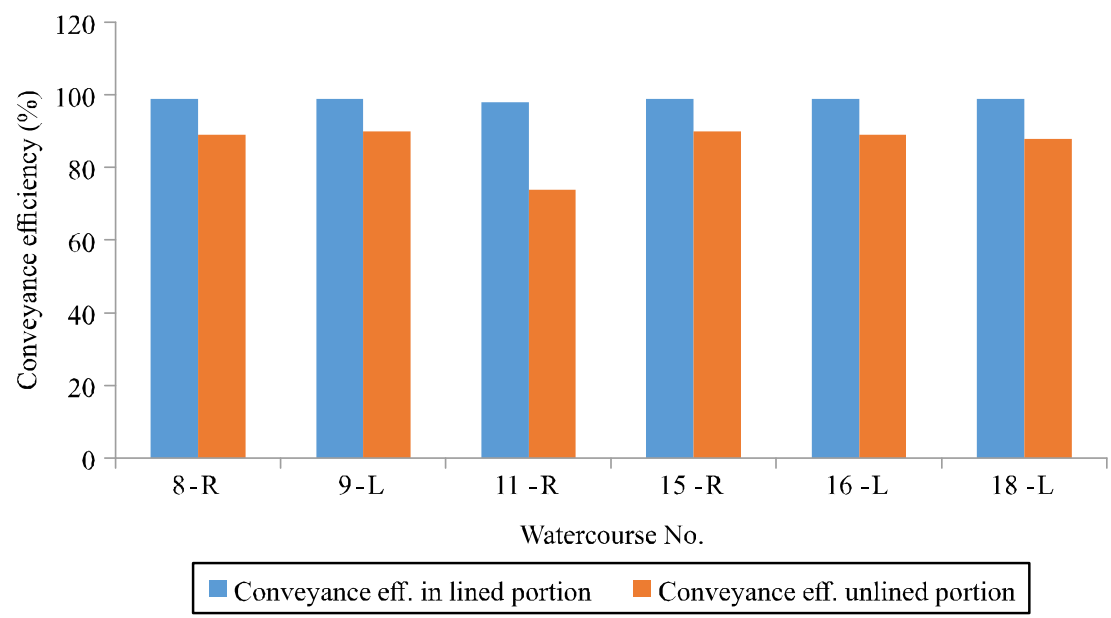

FIG. 3. CHANGE IN CONVEYANCE EFFICIENCY OBSERVED IN LINED AND UNLINED PORTIONS OF THE SAMPLE WATERCOURSES 


\subsection{Annual Water Saving}

The estimated water saving is described in Table 5 which shows annual water saving as 10.32 hectare-m through $30 \%$ lining of selected watercourses which could be used to irrigate more land. This was calculated by taking $1 \mathrm{~m}^{3 /}$ sec $=8.64$ hectare-m/day and 320 canal operational days .

\subsection{Cropping Pattern}

No any significant change regarding cropping pattern in the study area was observed after lining of sample watercourses but after lining of watercourses, the significant increase in cultivation of rice crop was observed.

\section{$3.5 \quad$ Cropping Intensity}

Table 6 shows that the percentage increase in annual cropping intensity of watercourses pre-and post-lining of 8-R, 9-L, 11-R, 15-R, 16-L and 18-L is 33, 35, 30, 31, 20 and $25 \%$ respectively.

\subsection{Crop Yield}

The data regarding yield of major crops grown in the command area of six watercourses selected for study is described in Table 7 and shown in Fig.4. It is obvious from the data that the crop yield was increased by $17 \%$ for wheat crop, $14 \%$ for cotton crop, $12 \%$ for sugarcane, $17 \%$ for chilies, $11 \%$ for onion crop and $20 \%$ for rice

TABLE 5. WATER SAVING AFTER IMPROVEMENT OF SELECTED WATERCOURSES

\begin{tabular}{|c|c|c|c|c|c|c|c|c|c|}
\hline \multirow[b]{2}{*}{$\begin{array}{c}\text { Watercourses } \\
\text { No. }\end{array}$} & \multicolumn{4}{|c|}{ Status of Water Quantum Before Lining } & \multicolumn{4}{|c|}{ Status of Water Quantum After Lining } & \multirow{2}{*}{$\begin{array}{c}\text { Annual } \\
\text { Water Saving } \\
\text { (hectare-m) }\end{array}$} \\
\hline & $\begin{array}{c}\text { Inlet Q } \\
\text { (cumecs) }\end{array}$ & $\begin{array}{l}\text { Outlet Q } \\
\text { (cumecs) }\end{array}$ & $\begin{array}{l}\mathrm{Q}_{\mathrm{L}} \\
(\%)\end{array}$ & $\begin{array}{c}\text { Annual } \\
\text { Water Loss } \\
\text { (hectare-m) }\end{array}$ & $\begin{array}{c}\text { Inlet Q } \\
\text { (cumecs) }\end{array}$ & $\begin{array}{l}\text { Outlet Q } \\
\text { (cumecs) }\end{array}$ & $\begin{array}{l}\mathrm{Q}_{\mathrm{L}} \\
(\%)\end{array}$ & $\begin{array}{c}\text { Annual } \\
\text { Water Loss } \\
\text { (hectare-m) }\end{array}$ & \\
\hline $8-\mathrm{R}$ & 0.0147 & 0.0132 & 10.2 & 4.1472 & 0.0148 & 0.0147 & 0.68 & 0.27648 & 3.87072 \\
\hline $9-\mathrm{L}$ & 0.0149 & 0.0134 & 10.1 & 4.1472 & 0.015 & 0.0149 & 0.67 & 0.27648 & 3.87072 \\
\hline $11-\mathrm{R}$ & 0.0407 & 0.0301 & 26.0 & 29.3068 & 0.0415 & 0.0407 & 1.93 & 2.21184 & 27.09504 \\
\hline $15-\mathrm{R}$ & 0.0418 & 0.0377 & 10.0 & 11.3356 & 0.0423 & 0.0418 & 1.18 & 1.3824 & 9.95328 \\
\hline $16-\mathrm{L}$ & 0.0305 & 0.0272 & 11.0 & 9.12384 & 0.0308 & 0.0305 & 0.97 & 0.82944 & 8.2944 \\
\hline $18-\mathrm{L}$ & 0.0295 & 0.0261 & 11.5 & 9.40032 & 0.0297 & 0.0295 & 0.67 & 0.55296 & 8.84736 \\
\hline \multicolumn{9}{|c|}{ Total } & 61.93152 \\
\hline \multicolumn{9}{|c|}{ Average Annual Water Saving (hectare-m) } & 10.32 \\
\hline
\end{tabular}

TABLE 6. REACH WISE CROPPING INTENSITY OF SELECTED WATERCOURSES

\begin{tabular}{|c|c|c|c|c|c|c|c|c|}
\hline \multirow[b]{2}{*}{ No. } & \multirow{2}{*}{$\begin{array}{c}\text { Watercourses } \\
\text { No. }\end{array}$} & \multicolumn{2}{|c|}{ Kharif 2015} & \multicolumn{2}{|c|}{ Rabi 2015-2016 } & \multicolumn{2}{|c|}{ Annual 2015-2016 } & \multirow{2}{*}{$\begin{array}{c}\text { Increase } \\
(\%)\end{array}$} \\
\hline & & $\begin{array}{c}\text { Before } \\
\text { Improvement }\end{array}$ & $\begin{array}{c}\text { After } \\
\text { Improvement }\end{array}$ & $\begin{array}{c}\text { Before } \\
\text { Improvement }\end{array}$ & $\begin{array}{c}\text { After } \\
\text { Improvement }\end{array}$ & $\begin{array}{c}\text { Before } \\
\text { Improvement }\end{array}$ & $\begin{array}{c}\text { After } \\
\text { Improvement }\end{array}$ & \\
\hline 1. & $8-\mathrm{R}$ & 68 & 85 & 71 & 87 & 139 & 172 & 33 \\
\hline 2. & 9-L & 69 & 87 & 71 & 88 & 140 & 175 & 35 \\
\hline 3. & $11-\mathrm{R}$ & 60 & 75 & 65 & 80 & 125 & 155 & 30 \\
\hline 4. & $15-\mathrm{R}$ & 65 & 80 & 65 & 81 & 130 & 161 & 31 \\
\hline 5. & $16-\mathrm{L}$ & 67 & 75 & 68 & 80 & 135 & 155 & 20 \\
\hline 6. & $18-\mathrm{L}$ & 66 & 78 & 70 & 83 & 136 & 161 & 25 \\
\hline \multicolumn{2}{|c|}{ Increase } & \multicolumn{2}{|c|}{$14 \%$} & \multicolumn{2}{|c|}{$15 \%$} & \multicolumn{2}{|c|}{$29 \%$} & Average $14.5 \%$ \\
\hline
\end{tabular}

Mehran University Research Journal of Engineering \& Technology, Volume 37, No. 1, January, 2018 [p-ISSN: 0254-7821, e-ISSN: 2413-7219] 
crop after $30 \%$ lining the watercourses. This increase in yield can be due to water saving or proper irrigation numbers applied to the crop after lining of the watercourses.

\subsection{Time Saving}

Table 8 shows that the average time consumed to irrigate an acre on different farm sizes, located on the head, middle and tail reaches of selected watercourses (average of six studied watercourses), there is time saving of 23 minutes at head, 27 minutes at middle and 40 minutes at tail of the selected watercourses. It means that there is a saving of $1 / 2$ hour on account of watercourse improvement program.

Due to lining, there are fewer chances of breaches and improvement in channel roughness occurs, therefore water flows with lesser resistance. As a result of that reduction in time to irrigate unit area occurs.

Hence in the present study more time saving (about 40 minutes) at tail of the selected watercourses was obtained.

\subsection{Labor Saving}

It was observed from the interviews of farmers that before improvement of watercourses, mostly two men even for single hectare land were required to irrigate the lands and in order to control and get water into the farm lands great difficulty was faced. But after watercourse improvement it is very easy to control the water. This was observed while diverting water even for single hectare of land because each stakeholder is allocated a proprietary right to draw all

TABLE 7. YIELD OF SOME COMMON CROPS CULTIVATED IN THE COMMAND AREA OF SAMPLE WATERCOURSES

\begin{tabular}{|c|c|c|c|c|}
\hline Type of Crop & $\begin{array}{c}\text { Before Lining } \\
\text { (mounds/hectare) }\end{array}$ & $\begin{array}{c}\text { After Lining } \\
\text { (mounds/hectare) }\end{array}$ & $\begin{array}{c}\text { Average Increase } \\
\text { (mounds/hectare) }\end{array}$ & Increase (\%) \\
\hline Wheat & 59 & 69 & 10 & 17 \\
\hline Cotton & 54 & 62 & 19 & 12 \\
\hline Sugarcane & 1655 & 1853 & 37 & 17 \\
\hline Chilies & 222 & 259 & 25 & 11 \\
\hline Onion & 222 & 247 & 18 & 20 \\
\hline Rice & 86 & 104 & 88 & 17 \\
\hline
\end{tabular}

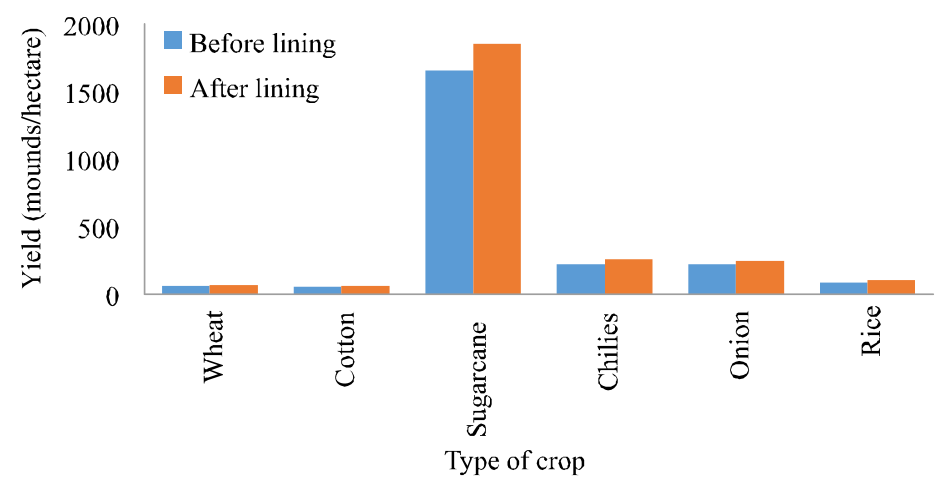

FIG. 4. OBSERVED CHANGE IN CROP YIELD BEFORE AND AFTER LINING OF THE SAMPLE WATERCOURSES 
the flow of the watercourse. Similar results have been observed by Khan et. al. [13] in their impact assessment study at Upper Chenab Canal System, Punjab, Pakistan.

\subsection{Land Saving}

It was also known that cross-section of lined watercourse has been reduced to about 30\% hence land has been saved and watercourses have become free from trees, bushes and silt deposits up to certain extent.

\subsection{Overall Water Balance in the lined and Unlined Sections of the Selected Watercourses}

Table 9 shows the overall water balance in lined and unlined sections of the studied watercourses. Overall $12 \%$ reduction of water losses was estimated by comparing the average conveyance loss of about $13 \%$ from unlined sections to the average conveyance loss of $01 \%$ from lined sections of the studied watercourses.

TABLE 8. AVERAGE TIME CONSUMED TO IRRIGATE AN ACRE ON SAMPLE WATERCOURSES

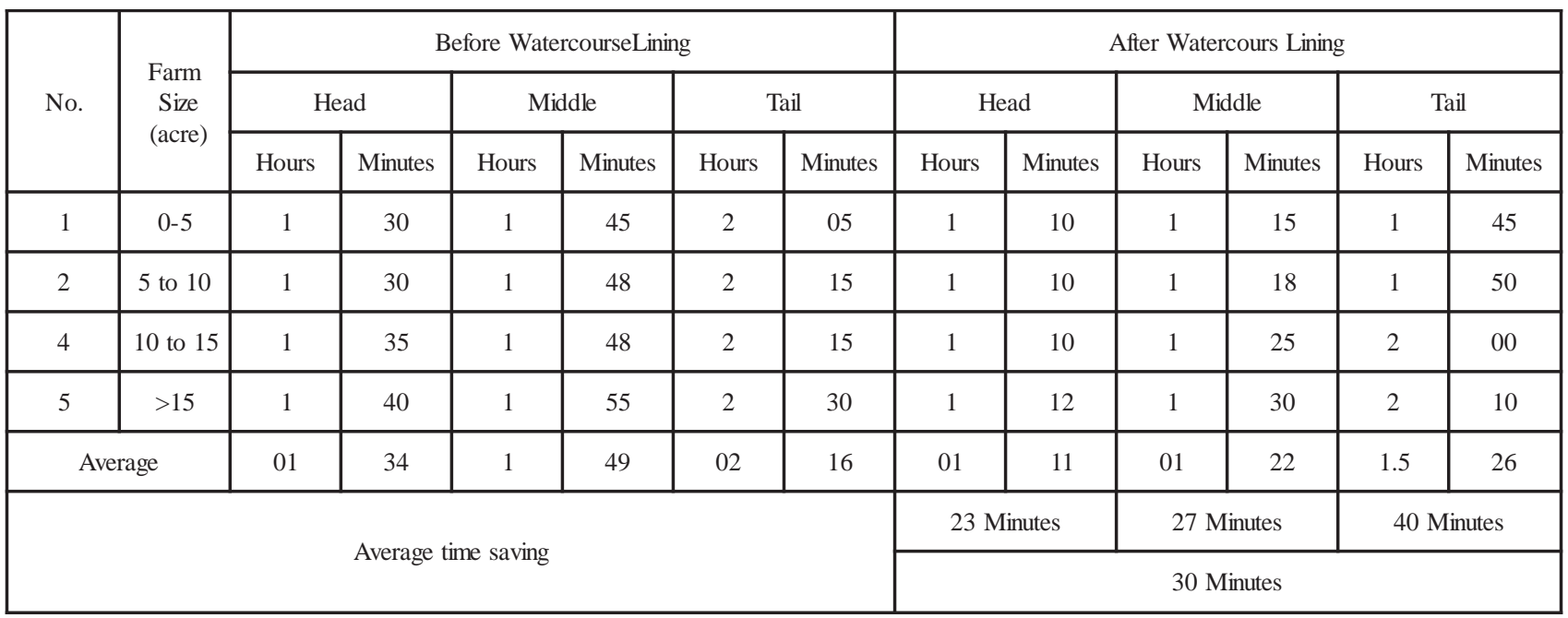

TABLE 9. OVERALL WATER BALANCE IN LINED AND ULINED SECTIONS OF THE SELECTED WATERCOURSES

\begin{tabular}{|c|c|c|c|c|c|c|c|c|}
\hline \multirow{2}{*}{$\begin{array}{c}\text { Watercourse } \\
\text { No. }\end{array}$} & \multicolumn{4}{|c|}{ Unlined Sections of the Watercourses } & \multicolumn{4}{c|}{ Lined Sections of the Watercourses } \\
\cline { 2 - 9 } & $\begin{array}{c}\text { Unlined Length } \\
(\mathrm{km})\end{array}$ & $\begin{array}{c}\text { Inlet Q } \\
(\mathrm{cumecs})\end{array}$ & $\begin{array}{c}\text { Outlet Q } \\
(\mathrm{cumecs})\end{array}$ & $\begin{array}{c}\mathrm{QL} \\
(\%)\end{array}$ & $\begin{array}{c}\text { Lined Length } \\
(\mathrm{km})\end{array}$ & $\begin{array}{c}\text { Inlet Q } \\
(\mathrm{cumecs})\end{array}$ & $\begin{array}{c}\text { Outlet Q } \\
(\mathrm{cumecs})\end{array}$ & $\begin{array}{c}\text { QL } \\
(\%)\end{array}$ \\
\hline $8-\mathrm{R}$ & 0.70 & 0.0147 & 0.0132 & 10.2 & 0.30 & 0.0148 & 0.0147 & 0.68 \\
\hline $9-\mathrm{L}$ & 0.84 & 0.0149 & 0.0134 & 10.1 & 0.36 & 0.015 & 0.0149 & 0.67 \\
\hline $11-\mathrm{R}$ & 2.667 & 0.0407 & 0.0301 & 26.0 & 1.143 & 0.0415 & 0.0407 & 1.93 \\
\hline $15-\mathrm{R}$ & 1.05 & 0.0418 & 0.0377 & 10.0 & 0.45 & 0.0423 & 0.0418 & 1.18 \\
\hline $16-\mathrm{L}$ & 1.05 & 0.0305 & 0.0272 & 11.0 & 0.45 & 0.0308 & 0.0305 & 0.97 \\
\hline $18-\mathrm{L}$ & 0.84 & 0.0295 & 0.0261 & 11.5 & 0.36 & 0.0297 & 0.0295 & 0.67 \\
\hline
\end{tabular}

Mehran University Research Journal of Engineering \& Technology, Volume 37, No. 1, January, 2018 [p-ISSN: 0254-7821, e-ISSN: 2413-7219] 


\section{CONCLUSION}

Comparing the average water loss of about $13 \%$ from unlined sections to the average water loss of about $01 \%$ from lined sections of watercourses, it was estimated that the lining decreased water loss by $12 \%$. Similarly average conveyance efficiency was increased by about $12 \%$ that resulted average annual water saving of 10.32 hectare-m which could be utilized to bring more land under cultivation for wheat and cotton crops during Rabi and Kharif seasons respectively. Moreover, the cropping intensity increased by $15 \%$ in Rabi and 14\% in Kharif seasons and 29\% annually in the command area of studied minor. Thus, it could be maintained that watercourse lining has substantial effect over water resource conservation.

\section{ACKNOWLEDGEMENT}

Authors are grateful to Irrigation Department, West Division Khairpur Mir's, for providing data and NPIW, FT Sobhodero for providing logistic support for this study.

\section{REFERENCES}

Dawadi, S., and Ahmad, S., "Evaluating the Impact of Demand-Side Management on Water Resources under Changing Climatic Conditions and Increasing Population”, Journal of Environmental Management, Volume 114, pp. 261-275, 2013.

Qaiser, K., Ahmad, S., Johnson, W., and Batista, J., "Evaluating Water Conservation and Reuse Policies using a Dynamic Water Balance Model”, Journal of Environmental Management, Volume 51, Nos. 2, pp. 449-458, 2013.

Ahmad, S., and Prashar, D., "Evaluating Municipal Water Conservation Policies using a Dynamic Simulation Model”, Journal of Water Resources Management, Volume 24, No. 13, pp. 3371-3395, 2010.
[4] Venkatesan, A.K., Ahmad, S., Johnson, W., and Batista, J., "Salinity Reduction and Energy Conservation in Direct and Indirect Portable Water Reuse”, Journal of Desalination, Volume 272, No. 1-3, pp. 120-127, 2011.

Wu, G., Li, L., Ahmad, S., Chen, X., and Pan, X., “A Dynamic Model for Vulnerability Assessment of Regional Water Resources in Arid Areas, A Case Study of Bayingolin, China”, Journal of Water Resources Management, Volume 27, No. 8, pp. 3085-3101, 2013.

[6] Haq, I., "Per Capita Water Availability Decreases in 2016”, http://www.brecorder.com/agriculture-a-allied/ 183:pakistan/23847:per-capita-water-availabilitydecreases-in-2016?date=2016-03-09. (Accessed on September 07, 2016)

[7] Corey, G.L., and Clyma, W., "The Importance of Farm Water Management in Pakistan”, Water Management Technical Report No. 38, College of Engineering, Colorado State University, pp. 1-28, Fort Collins, USA, 1975.

[8] Solangi, G.S., Qureshi, A.L., and Jatoi, M.A., "Impact of Rising Groundwater on Sustainable Irrigated Agriculture in the Command Area of Gadeji Minor, Sindh, Pakistan”, Mehran University Research Journal of Engineering \& Technology, Volume 36, No. 1, pp. 159-166, Jamshoro, Pakistan, January, 2017.

[9] Sultan, T., Latif, A., Shakir, A.S., Kheder, K.., and Rashid, M.U., "Comparison of Water Conveyance Losses in Unlined and Lined Watercourses in Developing Countries”, Technical Journal, University of Engineering \& Technology, Volume 19, No. 2, pp.23-27, Taxila, Pakistan, 2014.

[10] Waryam, A.M., and Rehmat, A., "Conveyance Losses in

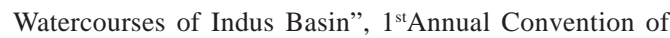
Pakistan, Society of Agricultural Engineers, Lahore, Pakistan, 1980.

[11] Khan, M.A., and Sadiq, M.A., "Socio-Economic Impact of Watercourse Improvement and Precision Land Leveling on Agriculture Production and Farmers Income”, Economic Studies Cell Agriculture Department, Lahore, Pakistan, 1987. 
[12] Mangrio, M.A., Lohano, A.M., Leghari, N., Khatri, K.L., Hyder, M., Shaikh, M.J., and Soothar, R.K., "Economic Feasibility of Watercourses Lining in Sindh, Pakistan", International Journal of Science (Lahore), Volume 27, No. 2, pp.1237-1242, 2015.
[13] Khan, M.N., Arshad, M., and Zaman, W., "Impact of Watercourses Improvement in the Upper Chenab Canal System of Punjab, Pakistan”, International Journal of Agriculture \& Biology, Volume 3, No. 2, pp. 1560-8530, 2001. 